\title{
Hubungan Beban Kerja Dengan Motivasi Kerja Pada Petugas Air Traffic Control (ATC) Bandara X
}

\author{
Widura Imam Mustopo* dan Agus Salim \\ Fakultas Psikologi Universitas Jayabaya \\ * Corresponding author: widurai@gmail.com
}

\begin{abstract}
Being an Air Traffic Control (ATC) officer is difficult, professionals are needed, and they have to be completely focused in order to create a safe air traffic condition. The purpose of this research is to find out the relation between workload and work motivation on ATC (Air Traffic Control) officer in airport $X$. The purpose of this research is to gain data about the relation between workload and work motivation on ATC office in airport $X$. This is a correlation research that is using the quantitative descriptive approach, while the data collection was conducted using the questioner method, the measuring instrument is an adaptation from NASA-TLX. The subjects for this research are 100 ATC officers in airport $X$. The correlation calculation result between workload and work motivation on ATC officers is 0,216, while significant level is 0,009. This research shows that there is a positive relation between workload and work motivation on ATC officers in airport X. In conclusion, if more workload is given to the ATC officers, it will increase their work motivation.
\end{abstract}

Abstrak

Menjadi petugas Air Traffic Control (ATC) merupakan hal yang tidak mudah, dibutuhkan profesionalisme, mereka harus bekerja dengan konsentrasi yang tinggi demi menciptakan kondisi lalu lintas penerbangan yang aman. Penelitian ini bertujuan untuk mengetahui hubungan antara beban kerja dengan motivasi kerja pada petugas ATC (Air Traffic Control) di Bandara X. Penelitian ini merupakan penelitian kuantitatif deskripfif, sedangkan pengumpulan data menggunakan metode kuesioner. Alat ukur beban kerja diadaptasi dari NASA-TLX. Subjek dalam penelitian adalah petugas ATC di bandara $\mathrm{X}$ berjumlah 100 orang. Hasil perhitungan korelasi antara beban kerja dengan motivasi kerja pada petugas ATC sebesar 0,261, dengan taraf signifikan 0,009. Hasil penelitian ini menunjukan bawah ada hubungan signifikan yang positif antara beban kerja dengan motivasi kerja pada petugas ATC di bandara $X$. Artinya, semakin bertambah beban kerja maka semakin meningkat motivasi kerja petugas ATC di Bandara X.

Keyword: Beban Kerja (Workload), Motivasi Kerja (Work Motivation), Air Traffic Control (ATC) 


\section{PENDAHULUAN}

Petugas pengatur lalu lintas pesawat udara disebut Air Traffic Controler (ATC). Petugas ATC bukanlah pekerjaan yang sederhana, mereka harus bekerja dengan konsentrasi tinggi untuk menciptakan kondisi lalu lintas penerbangan yang aman. Beban ker ja bisa berupa fisik maupun mental, untuk itu dibutuhkan kondisi fisik dan mental yang prima. Menurut Robbin \& Judge (2008) setiap pekerjaan dapat dianggap sebagai beban, tergantung pada persepsi tiap individu. Petugas ATC dituntut untuk melakukan tugas dan kegiatan yang membutuhkan aktivitas mental, fisik dan juga berpacu dengan waktu. Hal tersebut dapat berdampak positif ataupun negatif terhadap petugas ATC.

Menurut Robbin \& Judge (2008), positif negatifnya beban kerja merupakan masalah persepsi. Persepsi terhadap beban kerja berkaitan dengan faktor peran dan pekerjaan individu dalam memberikan penilaian mengenai sejumlah tuntutan tugas atau kegiatan yang membutuhkan aktivitas mental dan fisik yang harus diselesaikan dalam waktu tertentu, apakah hal tersebut memiliki dampak positif atau negatif terhadap pekerjaannya.

Dari dimensi beban kerja, menurut Tarwaka (2011) bila dihubungkan dengan kinerja mencakup: 1) Beban waktu (time load) menunjukan jumlah waktu yang tersedia dalam perencanaan, pelaksanaan dan monitoring tugas atau kerja, 2) Beban usaha mental (mental effort load) yaitu berarti banyaknya usaha mental dalam melaksanakan suatu pekerjaan, dan 3) Beban tekanan psikologis (psychological stress load) yang menunjukan tingkat risiko pekerjaan, kebingungan, dan frustrasi.

Motivasi sendiri merupakan dorongan dalam diri seseorang untuk melakukan suatu pekerjaan dalam rangka mencapai tujuan. Herzbeg, dkk. (1959) mengungkapkan bahwa motivasi individu dapat dipengaruhi faktor intrinsik dan faktor ekstrinsik. Faktor intrinsik adalah daya dorong yang timbul dari dalam diri masing-masing orang, seperti prestasi, pengakuan diri, sifat perkerjaan, tanggung jawab dan pengembangan karir. Sedangkan faktor ekstrinsik mencakup daya dorong yang datang dari luar diri seseorang, seperti . gaji, lingkungan kerja dan hubungan kerja. Melihat tanggung jawab besar yang diemban oleh petugas ATC, beban kerja yang sangat besar mungkin dapat membuat motivasi pekerja atau petugas berkurang. Namun demikian, beban kerja yang moderat mundkin saja malah membuat motivasi meningkat karena terkait dengan tanggung jawab yang masih dalam batas kemampouan individu untuk mengatasinya.

Alderfer (1969) seorang psikolog asal Amerika, m engembangkan teori hirarki kebutuhan Maslow yang dikenal dengan teori ERG. Aldelfer mengidentifikasi tiga kelompok kebutuhan yaitu: 1) Existence (Eksistensi), 2) Relatedness (Hubungan), dan 3) Growth (Perkembangan). Menurut Alderfer, pemenuhan ketiga kebutuhan tersebut dapat dilakukan secara simultan. Pada pendekatan Alderfer ada istilah frustasi-regresi, yaitu saat kebutuhan perkembangan yang berada di urutan lebih tinggi ditekan atau tidak terpenuhi karena berbagai keadaan, maka individu cenderung mundur kembali ke kebutuhan urutan yang lebih rendah dan lebih merasakan kebutuhan tersebut. Misalnya, ketika kebutuhan pertumbuhan buruk, maka seseorang akan termotivasu untuk mencapai kebutuhan yang berkaitan. J ika ada masalah dalam mencapai kebutuhan yang berkaitan, maka dia mungkin akan termotivasi oleh kebutuhan eksistensi. Menurut teori ERG, makin tidak terpenuhinya suatu kebutuhan tertentu, makin besar pula keinginan untuk memuaskannya. 
Menurut hasil penelitian Rindayani (2014) tentang pengaruh beban kerja dan motivasi terhadap kinerja pegawai, melaporkan bahwa beban kerja dan motivasi keduanya berpengaruh terhadap kinerja. Hasil penelitian Diani (2014) menunjukan motivasi kerja tidak berpengaruh terhadap kinerja, namun beban kerja berpengaruh secara signifikan terhadap kinerja. Semakin meningkat beban kerja semakin meningkat kerja seseorang. Penelitian lainnya oleh Sutoyo ( 2016) melaporkan bahwa beban kerja dan motivasi secara simultan berpengaruh terhadap kinerja. Beberapa penelitian telah memberikan hasil bahwa beban kerja dan motivasi namun belum ada hasil penelitian yang menunjukkan beban kerja berpengaruh terhadap motivasi kerja, sehingga hal itulah yang memunculkan pertanyaan penelitian, apakah ada hubungan antara beban kerja dengan motivasi kerja. Oleh karena itu, perlu diteliti secara empirik hubungan antara beban kerja dengan motivasi kerja pada petugas Air Traffic Control (ATC).

Berdasarkan uraian di atas, yang menjadi permasalahan dalam penelitian ini adalah apakah ada hubungan antara beban kerja dengan motivasi kerja pada petugas ATC. Tujuan penelitian adalah untuk mengetahui hubungan antara beban kerja dengan motivasi kerja pada petugas ATC.

\section{METODE PENELITIAN}

\section{Rancangan Penelitian}

Rancangan penelitian ini menggunakan pendekatan kuantitatif deskriptif dengan metode korelasional. Sedangkan pengumpulan data menggunakan skala untuk menggali data mengenai beban kerja dan motivasi kerja pada petugas ATC. Pengukuran dilakukan dengan menggunakan skala Likert yang disusun dan divalidasi melalui uji validitas dan reliabilitas. Uji validitas dan reliabilitas dilaksanakan dengan uji terpakai, artinya diuji secara parallel dengan pelaksanaan penelitian korelasional, item yang tidak valid tidak dihitung dalam penelitian.

\section{Identifikasi Variabel Penelitian}

a. Variabel Bebas (X) : Beban Kerja

b. Variabel Terikat (Y) : Motivasi Kerja

\section{Definisi Operasional Variabel Penelitian}

\section{Beban Kerja}

Beban Kerja adalah sekumpulan tugas atau pekerjaan berupa mental dan fisik yang ditanggung oleh pekerja yang harus diselesaikan pada rentang atau batas waktu tertentu demi mencapai tujuan dari organisasai, yang diukur melalui dimensi Mental Demand, Physical Demand, Temporal Demand, Performance dan Frustation Level.

\section{Motivasi Kerja}

Motivasi Kerja adalah dorongan dari dalam diri individu untuk melakukan suatu pekerjaan yang mengarah kepada tercapainnya tujuan tertentu dengan mengukur melalui dimensi Existence needs, Relatedness needs dan Growth needs. 


\section{Populasi dan Sampel Penelitian}

\section{Populasi}

Populasi dalam penelitian ini adalah petugas bandara X.

\section{Subjek Penelitian}

Subjek dalam penelitian ini adalah 100 orang petugas Air Traffic Control Bandara X

\section{Pengujian Alat Ukur}

\section{Skala Beban Kerja \\ Uji Validitas}

Perhitungan uji validitas koefisien korelasi (r) item dilakukan dengan bantuan program SPSS 20.0, menggunakan koefisien korelasi Product-Moment Pearson. Skala beban kerja dalam bentuk kuesioner ini diujikan secara lansung kepada sampel yang berjumlah 100 orang petugas Air Traffic Control (ATC) di bandara X. H a s i l p e r h i t u n g a $\mathrm{n} \mathbf{r}$ sebesar 0,1654 sehingga apabila nilai $r$ hitung $>r$ tabel berarti suatu item dinyatakan valid dan apabila $r$ hitung $<r$ tabel berarti suatu item dinyatakan tidak valid. Dari tabel di atas, setelah uji validitas dengan menggunakan rumus Product Moment Pearson, maka diperoleh 23 item valid dengan batas nilai $\mathrm{r}$ hitung $>0,1654$ dengan $\mathrm{N}=100.19$ item sisanya masuk dalam kategori tidak valid atau gugur dengan batas nilai $r$ hitung 0,1654 .

\section{Uji Validitas}

Perhitungan uji validitas koefisien korelasi (r) item dilakukan dengan bantuan program SPSS 20.0, menggunakan koefisien korelasi Product-Moment Pearson. Skala beban kerja dalam bentuk kuesioner ini diujikan secara lansung kepada sampel yang berjumlah 100 orang petugas Air Traffic Control (ATC) di bandara X. H a s i l p e r h i t u n g a $\mathrm{n} \mathbf{r}$ sebesar 0,1654 sehingga apabila nilai $r$ hitung $>r$ tabel berarti suatu item dinyatakan valid dan apabila $r$ hitung $<r$ tabel berarti suatu item dinyatakan tidak valid. Dari tabel di atas, setelah uji validitas dengan menggunakan rumus Product Moment Pearson, maka diperoleh 23 item valid dengan batas nilai $r$ hitung $>0,1654$ dengan $\mathrm{N}=100.19$ item sisanya masuk dalam kategori tidak valid atau gugur dengan batas nilai $\mathrm{r}$ hitung 0,1654 .

\section{Uji Reliabilitas}

Untuk menguji reliabilitas alat ukur dilakukan dengan menggunakan teknik pengukuran alpha crombach, dengan bantuan program SPSS 20.0. Dari hasil pengujian diperoleh reliabilitas $(\alpha)$ untuk skala beban kerja adalah sebesar 0,769 dari 23 item. Hasil pengujian tersebut menunjukan koefisien yang reliabel karena koefisien reliabilitas $(\alpha)$ memiliki nilai $>\mathrm{r}$ tabel yaitu 0,1654. Artinya dari 23 item yang terdapat pada skala ini sudah konsisten untuk dilakukan ke tahap penelitian. 


\section{Skala Motivasi Kerja}

\section{Teknik Pengujian Alat Ukur}

\section{Uji Validitas Skala Motivasi Kerja}

Skala Motivasi Kerja dalam bentuk kuesioner diujikan secara lansung kepada sample yang berjumlah 100 orang petugas Air Traffic Control (ATC) di bandara X. Hasil koefisien korelasi (r) sebesar 0,1654. Sehingga apabila nilai $r$ hitung $>r$ tabel berarti suatu item dinyatakan valid dan apabila $r$ hitung $<\mathrm{r}$ tabel berarti suatu item dinyatakan tidak valid. Skala beban kerja terdiri dari 38 item. Setelah d i 1 a k u k a n uji validitas dengan rumus Product Moment Pearson, dari 38 item diperoleh 35 item yang valid dengan batas nilai $\mathrm{r}$ hitung $>0,1654$ dengan $\mathrm{N}=100$. Tiga item sisanya masuk dalam kategori tidak valid atau gugur dengan batas nilai $\mathrm{r}$ hitung 0,1654 .

\section{Uji Reliabilitas Skala Motivasi Kerja.}

Dari hasil pengujian diperoleh reliabilitas Alpha Cronbach $(\alpha)$ skala beban kerja sebesar 0,783 dari 35 item. Hasil uji tersebut menunjukan koefisien yang reliabel karena $(\alpha)$ memiliki nilai > $r$ tabel yaitu 0,1654. Artinya 35 item yang terdapat pada skala ini sudah konsisten untuk dilakukan ke tahap penelitian.

\section{Analisis Data}

Metoda analisis data dalam penelitian ini didasarkan atas tujuan penelitian, yaitu untuk mengetahui hubungan antara beban kerja dengan motivasi pada pada petugas ATC di bandara $\mathrm{X}$. Data penelitian ini dianalisis menggunakan uji korelasi product moment. Teknik ini digunakan karena kedua jenis data yang akan dikorelasikan berbentuk ordinal. Dalam pengerjaanya, uji korelasi akan dilakukan dengan bantuan program aplikasi komputer SPSS 20.

\section{HASIL DAN PEMBAHASAN}

\section{Hasil Analisis Korelasi}

Hasil analisis korelasi beban kerja dengan motivasi kerja pada petugas ATC menggunakan uji Pearson Product Moment.

Tabel 4.1

\section{Korelasi Beban Kerja}

\begin{tabular}{|cl|c|c|}
\hline Correlation & & Beban Kerja & Motivasi \\
\hline Beban Kerja & Pearson Correlation & 1 &, $261^{* *}$ \\
& Sig. (2-tailed) & 100 &, 009 \\
& N &, $261 * *$ & 100 \\
\hline Motivasi & Pearson Correlation &, 009 & 1 \\
& Sig. (2-tailed) & 100 & 100 \\
& N & & \\
& $* *$. Correlation is significant at the 0.01 level (2-tailed).
\end{tabular}


Dari tabel diatas dapat dilihat hasil penelitian antara Beban Kerja dengan Motivasi Kerja, dapat diperoleh nilai signifikansi sebesar 0,009. Dari hasil tersebut, dapat dilihat bahwa $p$ value (nilai signifikan) < alpha $(\alpha)$ yaitu $0,01(1 \%)$. Jadi $\mathrm{H}_{0}$ ditolak dan $\mathrm{H}_{1}$ diterima. Artinya ada hubungan yang signifikan antara beban kerja denga motivasi kerja.

\section{Pembahasan}

Berdasarkan dari analisis korelasi antara beban kerja dengan motivasi kerja pada petugas ATC di bandara $X$ didapatkan bahwa ada hubungan signifikan antara beban kerja dengan motivasi kerja pada petugas ATC di bandara X. Hal itu menunjukkan bahwa beban kerja berhubungan dengan motivasi kerja pada petugas ATC. Artinya semakin b e s a r beban kerja semakin meningkat juga motivasi kerja pada petugas ATC.

Petugas ATC merupakan tenaga profesional yang melalui beberapa proses sebelum terjun ke dunia pekerjaan artinya mereka memang telah dipersiapkan untuk menjadi petugas yang terlatih, selama masa pendidikan mereka telah diperkenalkan dengan penggunaan alat dan praktik kerja di lapangan, yang membuat petugas mempersiapkan dirinya untuk beradaptasi dengan lingkungan kerja, dan sistem kerja sebelum menjadi petugas ATC. Bekerja sebagai ATC memerlukan konsentrasi yang tinggi, pengambilan keputusan cepat, beban kerja yang bertambah seperti padatnya jadwal penerbangan. sudah dianggap oleh mereka seperti hal yang biasa dikarenakan petugas memang telah sudah terlatih untuk menghadapi hal tersebut, selain itu lama bekerja stiap petugas yang rentang waktunya di atas tiga tahun yang artinya mereka mempunyai jam kerja yang banyak membuat petugas pun sudah beradaptasi dengan pekerjaannya. Beban kerja dianggap sebagai suatu tantangan bagi petugas, ketika dapat mengerjakannya dengan benar dan tepat akan menumbuhkan kebanggan yang selanjutnya dapat menambah kepercayaan diri bagi petugas.

Dukungan dan penghargaan bagi petugas yang berprestasi didapat dari rekan kerja atau pimpinan sehingga membuat hubungan yang baik antara rekan kerja dan juga atasan. Pada saat terjadi kesulitan atau hambatan dalam bekerja, mereka saling memberikan saran dan masukan, pimpinan atau supervisor memberikan arahan dan membantu bawahannya. Adanya kerja sama diantara mereka dapat meringankan tugas satu sama lain, sehingga beban kerja yang meningkat membuat motivasi kerja akan meningkat.

Berprofesi sebagai petugas ATC merupakan suatu tanggung jawab yang besar mereka berusaha untuk menjaga keselamatan dalam penerbangan, dengan adanya tanggung jawab yang penuh terhadap tugasnya dia akan melakukan kewajiban terhadap tugas tanpa terpengaruh oleh beban kerja yang ada, bahkan dia termotivasi dalam bekerja dengan tanggung jawab yang dia dapat, selain bertanggung jawab dipekerjaan mereka juga harus bertanggung jawab juga terhadap keluarga, yaitu bekerja dengan baik dan mendapatkan gaji untuk memenuhi kebutuhan primer dan sekunder. Profesi sebagai ATC yang memiliki beban kerja yang besar, petugas ATC mendapat gaji yang sesuai dengan pekerjaannya dan dirasa sudah cukup untuk memenuhi kebutuhan sehari hari setiap petugas dan sudah sesuai dengan pekerjaan yang dilakukan.

Selain dari gaji dari pihak manajemen perusahaan memperhatikan kesejahteraan dan fisiologis dengan memberikan tunjangan, pengecekan kesehatan tiap beberapa bulan, mengatur waktu bekerja, memberikan waktu istirahat yang cukup, dan memberi sarana prasarana yang menunjang segala kegiatan yang berhubungan dengan pekerajaan dari petugas itu sendiri dengan memberikan fasilitas, selain memberikan fasilitas sistem kerja yang telah diatur oleh manajemen sangat membantu menunjang pekerjaan. Lingkungan kerja yang nyaman, rapi, 
sehat, pengecekan peralatan yang digunakan, dan pengadaan peralatan kerja yang baru, beban kerja yang bertambah diringankan dengan adanya bantuan dari pihak manajemen sehingga membantu petugas ATC dalam bekerja. Manajemen perusahaan juga melakukan peningkatan kualitas dari sumber daya manusia atau petugas ATC berupa mengikut sertakan pegawai dalam pendidikan, pelatihan dan mendatangkan tenaga ahli dari luar negeri untuk dapat meningkatkan pengetahuan dan keterampilan petugas, pengetahuan dan keterampilan yang diperoleh membantu petugas dalam melakukan pekerjaan. Dengan bertambahnya beban kerja, pihak manajemen memberikan dukungan berupa sarana prasarana, pelatihan dan gaji yang sesuai dengan kebutuhan petugas ATC.

\section{KESIMPULAN DAN SARAN}

Berdasarkan hasil penelitian dapat disimpulkan bahwa terdapat hubungan yang signifikan antara beban kerja dengan motivasi kerja.

Berdasarkan temuan yang diperoleh dalam penelitian ini, terdapat beberapa saran, antara lain:

a. Penelitian selanjutnya perlu membandingkan hasil dengan menggunakan alat ukur baku NASA-TLX atau SWAT atau Modified Cooper Harper Scalling ataupun Rating Scale Mental Effort.

b. Membandingkan hasil pengukuran beban kerja dan motivasi kerja serta hubungan kedua variable tersebut dengan Bandara dengan tingkat kesibukan ATC yang tinggi.

\section{UCAPAN TERIMAKASIH}

Penelitian ini dapat dilaksanakan berkat dukungan pimpinan Bandara $\mathrm{X}$ yang telah memberikan kesempatan dan waktu yang cukup untuk mengambil data penelitian. Untuk itu dukungan tersebut, peneliti mengucapkan terimakasih. Tidak lupa apresiasi kami berikan kepada para petugas ATC Bandara $\mathrm{X}$ yang telah memberikan respon yang baik dalam mengisi skala kuesioner di sela-sela kesibukannya dalam bekerja. Semoga semua dukungan dan bantuan tersebut mendapatkan Rahmat Allah SWT. Aamiin. 


\section{DAFTAR PUSTAKA}

Ahmad, K. (1996). Dasar-dasar Manajemen Investasi. Jakarta : Rineka. Cipta

Alderfer, C.P. (1969). An Emprical Test of a New Theory of Human Needs, Organization Behavioral and Human Performance.

Anastasi, A., \& Urbina, U., (1997). Psychological Testing ( $7^{\text {th }}$ ed.). New Jersey: Prentice-Hall, Inc.

Brahmasari, I.A. \& Suprayetno, A. (2008). Pengaruh Motivasi Kerja, Kepemimpinan dan Budaya Organisasi Terhadap Kepuasan Kerja Karyawan serta Dampaknya pada Kinerja Perusahaan (Studi kasus pada PT. Pei Hai International Wiratama Indonesia). Jurnal Manajemen Vol.2, No.2, 124-135.

Dhania, D.R. (2010). Pengaruh Stres Kerja, Beban Kerja Terhadap Kepuasan (Studi Pada Medical Representatif di Kota Kudus), Vol I.

Diani, D.T., \& Kusni Ingsih, (2014). Pengaruh Motivasi Kerja, Disiplin Kerja, dan Beban Kerja Terhadap Kinerja Bidan di Instalasi Rawat Inap Ruang Obstetri RSUP Dr. Kariadi Semarang.

Gopher, D., \& Donchin, E. (1986). Workload: An Examination of the Concept. Psychology Faculty Publications. 283. https://scholarcommons.usf.edu/psy_facpub/283

Haris, W.C., Hancock, P.A., Arthur, E.J., \& Caird, J.K. (1995). Workload, and Fatigue Changes Associated With Automation, MN 56002- 8400.

Hariyono, W., Suryani, S., \& Wulandari, Y. (2009). Hubungan antara Beban Kerja, Stres Kerja dan Tingkat Konflik dengan Kelelahan Kerja Perawat di Rumah Sakit Islam Yogyakarta PDHI Kota Yogyakarta, Jurnal KESMAS UAD, Vol. 3. 162-232.

Hasibuan. M.S.P. (1990). Manajeman Sumber Daya Manusia, Dasar dan Kunci Keberhasilan. Jakarta: Gunung Agung.

Hasibuan, M. (2003). Organisasi dan Motivasi Dasar Peningkatan Produktivitas. Jakarta: Bumi Aksara.

Herzberg, F., Mausner, B., \& Snyderman, B.-C. (1959). The Motivation to Work. New York: John Willey \& Sons.

Hidayat, T.F., Pujangkoro, S. \& Anizar. (2013). Pengukuran Beban Kerja Perawat Menggunakan Metode NASA-TLX di Rumah Sakit XYZ. FT USU: e- Jurnal Teknik Industri. 1(2), pp.42-47. 
Kreitner, R., \& Angelo, K. (2005). Perilaku Organisasi (Orgaizational Behavior). Jakarta: Salemba Empat.

Luthan, F. (2016). Perilaku Organisasi. Terjemahan. Yogyakarta: Penerbit Andi.

Menteri Dalam Negeri. (2008). Peraturan Menteri Dalam Negeri Nomor 12 Tahun 2008 Tentang Pedoman Analisis Beban Kerja Di Lingkungan Departemen Dalam Negeri Dan Pemerintah Daerah. Jakarta: Kementerian Dalam Negeri Republik Indonesia

Menteri Pendayagunaan Aparatur Negara dan Reformasi Birokrasi. (2020). Peraturan Menteri Pendayagunaan Aparatur Negara Dan Reformasi Birokrasi Republik Indonesia Nomor 1 Tahun 2020 Tentang Pedoman Analisis Jabatan Dan Analisis Beban Kerja. Jakarta: Kementerian Pendayagunaan Aparatur Negara dan Reformasi Birokrasi Republik Indonesia.

Mudayana, A,A. (2010). Pengaruh Motivasi dan Beban Kerja Terhadap Kinerja Karyawan di Rumah Sakit Nur Hidayah, Vol. 4 No.2. 76-143.

Munandar. A.S. (2001). Psikologi Industri dan Organisasi. Jakarta : UI.

Mutia, M. (2014). Pengukuran Beban Kerja Fisiologis dan Psikologis pada Operator Pemetik Teh dan Operator Produksi Teh Hijau di PT Mitra Kerinci, Vol.13, No.1, 503-507.

Pudjirahardjo. W.J., Rivai, F., \& Hargono, R. (2013). Faktor Dominan yang Mempengaruhi Kinerja Perawat dalam Melaksanakan Asuhan Keperawatan di Ruang Rawat Inap RSU Haji Surabaya. Jurnal Administrasi Kesehatan Indonesia, Vol. 1. 2013. Surabaya.Universitas Airlangga.

Reid, G.B., (1989). Subjective Workload Assessment Technique (SWAT): A User's Guide, Harry G. Armstrong Medical Research-Wright Patterson. Ohio: Air Force Base.

Rindayani, R. (2014). Pengaruh Beban Kerja dan Motivasi Terhadap Kinerja Pegawai Biro Umum Sekretariat Jenderal Pekerjaan Umum Jakarta. Skripsi. Program Studi Manajemen Fakultas Ekonomi, Institut Bisnis dan dan Informatika Kosgoro 1957.

Robbins, S.P., \& Judge, T.A. (2008), Perilaku Organisasi, Edisi 12, Jilid 1 \& 2, Terjemahan. Jakarta: Penerbit Salemba Empat.

Sum'mur. (1978). Higene Perusahaan dan Kesehatan Kerja. Jakarta: Gunung Agung.

Sutoyo. (2016). Pengaruh Beban Kerja, Lingkungan Kerja dan Motivasi Terhadap Kinerja Pegawai Pada Dinas Bina Marga Propinsi Sulawesi Tengah. Jurnal Katalogis. Vol 4, No

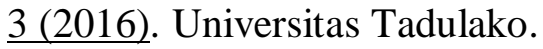

Tarwaka. (2011). Ergonomi untuk Keselamatan Kesehatan Kerja dan Produktivitas. Surakarta: Harapan Press.

Vroom, V.H. (1964). Work and Motivation. New York: John Wiley \& Sons. 
Winardi. (2001). Motivasi \& Pemotivasian dalam Manajemen. Jakarta: PT. Raja Grafindo Persada.

Wirawan, S. (1999). Psikologi Sosial, I dan II, Jakarta: Balai Pustaka.

DOI : https://doi.org/10.31479/intensi.v1i1.4 